\title{
Serological and virological surveys of the influenza A viruses in Antarctic and sub-Antarctic penguins
}

\author{
F. XAVIER ABAD ${ }^{1 *}$, NÚRIA BUSQUETS ${ }^{1 *}$, AZUCENA SANCHEZ ${ }^{2}$, PETER G. RYAN $^{3}$, NATÀLIA MAJÓ $^{1,4}$ and \\ JACOB GONZALEZ-SOLÍS ${ }^{5}$ \\ ${ }^{I}$ CReSA, Centre de Recerca en Sanitat Animal, UAB-IRTA, 08193 Bellaterra (Cerdanyola del Vallès), Spain \\ ${ }^{2}$ Departamento de Enfermedades Emergentes, Laboratorio Central de Veterinaria, Ctra. Algete, km 8, 28110 Algete, Madrid, Spain \\ ${ }^{3}$ Percy FitzPatrick Institute, DST/NRF Centre of Excellence, University of Cape Town, Rondebosch 7701, South Africa \\ ${ }^{4}$ Departament de Sanitat $i$ Anatomia Animals, Universitat Autònoma de Barcelona, 08193 Bellaterra, Barcelona, Spain \\ ${ }^{5}$ Institut de Recerca de la Biodiversitat (IRBio) and Dept Biologia Animal, Universitat de Barcelona, Av. Diagonal, 643, \\ 08028 Barcelona, Spain \\ xavier.abad@cresa.uab.cat \\ *These authors contributed equally to this work.
}

\begin{abstract}
To evaluate the avian influenza virus (AIV) circulation in Antarctic and sub-Antarctic penguins we carried out a serosurvey on six species from Livingston, Marion and Gough islands. Seropositivity against AIV was performed on serum samples using a competitive enzyme-linked immunosorbent assay and haemagglutination and neuraminidase inhibition assays. Some oropharyngeal and cloacal swabs were also assayed to detect influenza virus genomes by real time reverse transcription-polymerase chain reaction. Overall, $12.1 \%(n=140)$ penguins were seropositive to AIV. By species, we detected 5\% $(n=19)$ and $11 \%$ $(n=18)$ seroprevalence in sub-Antarctic rockhopper penguins (Eudyptes spp.) from Gough and Marion islands, respectively, $42 \%(n=33)$ seroprevalence in macaroni penguins (Eudyptes chysolophus Brandt), but no positives in the three other species, gentoo (Pygoscelis papua Forster; $n=25$ ) and chinstrap penguins ( $P$. antarctica Forster; $n=16$ ), from Livingston Island and king penguins (Aptenodytes patagonicus Miller; $n=27$ ) from Marion Island. While seropositivity reflected previous exposure to the AIV, the influenza genome was not detected. Our results indicate that AIV strains have circulated in penguin species in the sub-Antarctic region, but further studies are necessary to determine the precise role that such penguin species play in AIV epidemiology and if this circulation is species (or genus) specific.
\end{abstract}

Received 19 March 2012, accepted 15 November 2012

Key words: antibodies, ASPA, avian pathogens, influenza prevalence, marine animals

\section{Introduction}

Influenza A viruses infect many species, including humans, pigs, marine mammals, and a wide range of birds, including both domestic and wild species (Webster et al. 1992). Anseriformes and Charadriiformes are the natural hosts of avian influenza viruses (AIV). All 16 haemagglutinin (HA or $\mathrm{H}$ ) and nine neuraminidase (NA or $\mathrm{N}$ ) subtypes have been reported from these bird orders, although they are not evenly distributed among species and locations (Webster et al. 1992, Olsen et al. 2006). Recently, a new type of HA, designated as H17, has been isolated (Tong et al. 2012). In wild waterfowl, AIV infections are usually caused by low pathogenic avian influenza viruses (LPAIV), which are asymptomatic or associated with mild clinical signs, as they are thought to have co-adapted and evolved to replicate at high levels causing mild or no pathological effects in the host (Webster et al. 1992). It is generally accepted that highly pathogenic avian influenza viruses (HPAIV), responsible for high mortality in gallinaceous birds, do not have wild reservoirs, but that these strains emerge from
LPAIV precursors once introduced to poultry (Capua \& Alexander 2006). However, since the emergence of HPAIV H5N1 caused mortalities in more than 109 wild bird species (USGS http://www.nwhc.usgs.gov/disease_ information/avian_influenza/affected_species_chart.jsp, accessed 3 December 2012), the paradigm regarding AIV and wild birds is changing. The H5N1 HPAI outbreak in the northern hemisphere has increased concerns regarding the role of wild birds in influenza virus transmission.

Although extensive data are available on LPAIV surveillance in wild birds in North America and Eurasia (Olsen et al. 2006, Munster et al. 2007), data are scarce for other parts of the world, including much of the Southern Hemisphere (Munster et al. 2007, Cumming et al. 2008, Ghersi et al. 2009, Abolnik et al. 2010, Brown et al. 2010, Bulach et al. 2010). In particular, our understanding of LPAIV ecology in the natural reservoir in Antarctic ecosystems is still far from complete, partly due to the difficulty of sampling in this environment. Despite their geographic isolation, these habitats are vulnerable to new pathogens (bacterial and viral) and parasites, such as AIV, 


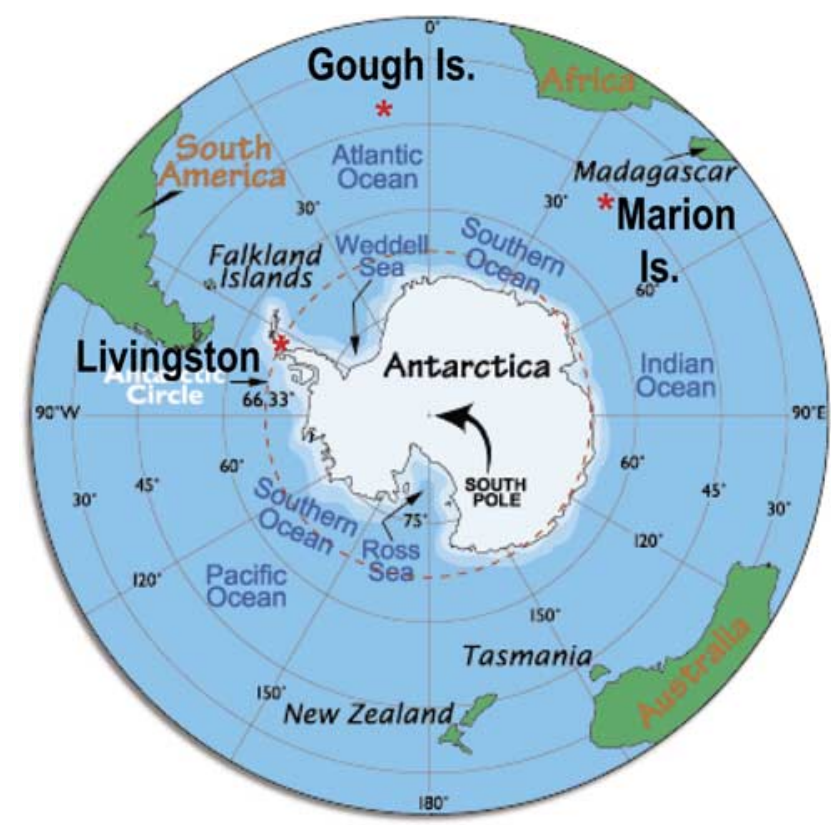

Fig. 1. Map showing the location of sampling sites.

that can severely affect wild bird species due to their less effective immunological systems in such harsh environments (Weimerskirch 2004, Møller et al. 2009). In addition, increasing temperatures in polar environments with low ecological diversity can open the way for pathogen range expansion, host switching and disease emergence, with potentially significant consequences for the health of wildlife populations (Davidson et al. 2011).

Influenza viruses show weak independent dispersal abilities and therefore must rely on proximity among individuals and contact with faeces for transmission (i.e. it depends directly on the ecology and behaviour of its seabird host). Among seabirds, penguins form particularly dense and large breeding colonies of tens or even hundreds of thousands of pairs distributed mainly throughout the sub-Antarctic and Antarctic archipelagos and the Antarctic continent. Most species are surface nesters and faeces accumulate on the ground during the breeding season, facilitating the close contact between individuals and their faeces, and therefore the transmission of faecal-borne viruses. The first AIV serosurvey on penguins was performed 30 years ago (Morgan \& Westbury 1981, Morgan et al. 1981), and since then, several surveys of AIV have been reported from seabirds in the region (Austin \& Webster 1993, Briggs et al. 2003, Wallensten et al. 2006), showing serologic evidence but no isolation of AIV (Munster et al. 2007). Previous studies have concluded that very little seroprevalence to AIV occurs in penguins (Clarke \& Kerry 2000) or more widely in Antarctic birds (Barbosa \& Palacios 2009). This paper evaluates the exposure of penguins to AIV and its potential circulation at three major breeding sites from $40^{\circ}-63^{\circ} \mathrm{S}$ : Gough Island $\left(40^{\circ} \mathrm{S}, 10^{\circ} \mathrm{W}\right)$ in the central South Atlantic, Marion Island $\left(47^{\circ} \mathrm{S}, 38^{\circ} \mathrm{E}\right)$, the larger of the two Prince Edward islands in the south-west Indian Ocean, and Livingston Island $\left(63^{\circ} \mathrm{S}, 61^{\circ} \mathrm{W}\right)$ South Shetland Islands (Fig. 1). Given that the number of natural host species for AIV in the Antarctic and sub-Antarctic is limited, that penguins in the region are philopatric and rarely disperse north of $40^{\circ} \mathrm{S}$, and that poultry animals have not been taken to any of our study areas for more than roughly 50 years, we would expect a low circulation of $\mathrm{AI}$ among these penguins.

\section{Materials and methods}

\section{Collection of samples}

Blood samples were collected from two penguin species in the surroundings of the Spanish polar station (62 $\left.66^{\prime} 40.90^{\prime \prime} \mathrm{S}, 61^{\circ} 09^{\prime} 98.00^{\prime \prime} \mathrm{W}\right)$ on Byers Peninsula (an Antarctic Specially Protected Area, ASPA No. 126), Livingston Island $(n=43)$ in January 2009, one penguin species on Gough Island $(n=19)$ in September 2009, and three on Marion Island $(n=78)$ in April 2011 (Table I). Blood, oropharyngeal and cloacal samples were obtained from 140 adult penguins. Blood was taken from the flipper, centrifuged for ten minutes at $10000 \mathrm{rpm}$ to separate the serum, and frozen until analysis. Oropharyngeal and cloacal samples were obtained through the insertion of a sterile cotton wool swab into the trachea and cloacae respectively. The swabs were placed in phosphate buffered

Table I. Penguin species tested for antibodies against influenza virus using competitive enzyme-linked immunosorbent assay.

\begin{tabular}{|c|c|c|c|c|c|}
\hline \multicolumn{2}{|c|}{ Penguin species } & \multicolumn{3}{|c|}{ Number of birds examined } & \multirow{2}{*}{$\begin{array}{l}\text { No. of positives } \\
\text { (\% prevalence) }\end{array}$} \\
\hline Common name & Scientific name & $\begin{array}{l}\text { Gough } \\
\text { Island }\end{array}$ & $\begin{array}{c}\text { Marion } \\
\text { Island }\end{array}$ & $\begin{array}{l}\text { Livingston } \\
\text { Island }\end{array}$ & \\
\hline Southern rockhopper & E. chrysocome (Sibley \& Monroe) & - & 18 & - & $2(11 \%)$ \\
\hline Macaroni & E. chrysolophus Brandt & - & 33 & - & $14(42 \%)$ \\
\hline Chinstrap & Pygoscelis antarctica Forster & - & - & 17 & $0(0 \%)$ \\
\hline Gentoo & P. papua Forster & - & - & 26 & $0(0 \%)$ \\
\hline Total & & 19 & 78 & 43 & $17 / 140(12.1 \%)$ \\
\hline
\end{tabular}


saline and stored at $-20^{\circ} \mathrm{C}$ and then at $-75^{\circ} \mathrm{C}$ until analyses were conducted.

Samples were collected in the field from live-captured un-anesthetized animals that were released immediately after the samples were obtained, without additional protection measures as adults are not predated. All individuals were captured by hand. Chinstrap penguins (Pygoscelis antarctica) were captured from the beach and gentoo penguins (P. papua) from the Devil's Point rockery, when birds were arriving from foraging.

\section{Serological assay}

Blood serum samples were analysed using the commercial competitive enzyme-linked immunosorbent assay (cELISA; ID Screen ${ }^{\circledR}$ Influenza A Antibody Competition, ID Vet, Montpellier, France), according to the manufacturer's instructions. This ELISA was designed to detect antibodies directed against the A nucleoprotein of AIV among horses, pigs and various avian species.

\section{Haemagglutination inhibition and neuraminidase inhibition assays}

Serum subtyping was carried out by haemagglutination inhibition (HI) and neuraminidase inhibition (NI) assays using specific chicken antisera to the reference strains of influenza virus against all $16 \mathrm{HA}$ and nine NA subtypes following standard protocols (OIE 2009) in the Reference Veterinary Laboratory in Spain (Algete) and starting at $1 / 8$ dilution of the serum.

\section{Real time reverse transcription-polymerase chain reaction $(R R T-P C R)$}

Oropharyngeal and cloacal swabs from AIV seropositive individuals were analysed by a TaqMan RRT-PCR to detect AIV using the primers and probe described by Spackman et al. (2002), and following the amplification conditions described by Busquets et al. (2010) in a Fast7500 analyser (Applied Biosystems, Foster City, CA). Briefly, viral RNA was extracted using a QIAamp Viral RNA extraction kit (Qiagen, Valencia, CA) obtaining $40 \mu \mathrm{l}$ of eluted viral RNA. The $M$ gen fragment amplification was performed using the commercial One-Step RT-PCR Master Mix Reagents (Applied Biosystems, Foster City, CA) and using $5 \mu \mathrm{l}$ of eluted RNA in a total volume of $25 \mu \mathrm{l}$.

\section{Results}

Seventeen of $140(12.1 \%$; 95\% CI: $7.2-18.7 \%)$ serum samples were positive to antibodies against AIV. All 17 occurred among crested penguins Eudyptes spp., with seropositive individuals among samples of southern rockhopper (Eudyptes chrysocome) and macaroni penguins
(E. chrysolophus) from Marion Island, and northern rockhopper penguins (E. moseleyi) from Gough Island. Seroprevalence was significantly greater $(P<0.05$ test $P$ Fisher) in macaroni penguins than the other two Eudyptes species (Table I). We could not detect any positive reaction among chinstrap Pygoscelis antarctica or gentoo P. papua penguins (sampled from Devils Point colony $62^{\circ} 40^{\prime} \mathrm{S}$, $\left.61^{\circ} 13^{\prime} \mathrm{W}\right)$ from Livingston Island or king penguins (Aptenodytes patagonicus) from Marion Island (Table I). The HI and NI assays of seropositive penguins, to determine which specific AIV subtypes the penguins had been exposed to, tested positive for four of 14 macaroni penguins (to both $\mathrm{HI}$ and NI assays; none of the rockhopper penguins tested positive). However, we could only confirm exposure to AIV N5 in one macaroni penguin. Oropharyngeal or cloacal shedding of AIV was not detected by RRT-PCR in any northern rockhopper penguins $(n=19)$ or in any of the AIV seropositive penguins from Marion Island.

\section{Discussion}

Birds of wetlands and aquatic environments are thought to be the major natural reservoir for AIV. The prevalence of AIV in their natural hosts depends on the locality, seasonality and the species (Olsen et al. 2006). Antarctic animals are not beyond the risk of emerging infectious diseases. They can be affected by pathogens under harsh environments, which can compromise their immunological systems (Møller et al. 2009). Overall, 12\% of penguins sampled in our study were seropositive, suggesting they had been previously exposed to the AIV. As far as we know, the presence of such antibodies does not correlate with any previous overt clinical disease report in the assayed species. We detected low seroprevalence in rockhopper penguins from two localities in the subAntarctic, Gough and Marion islands, medium to high seroprevalence in macaroni penguins from Marion Island, but no positives in the other penguin species, irrespective of sampling location. However, we have to bear in mind that the absence of AIV antibodies does not necessarily mean that they never occurred in a specific species, since the persistence time of antibodies in penguins is still unknown and may differ between species.

Very little seroprevalence to AIV has been detected in penguins (Clarke \& Kerry 2000) and most studies have failed at all to track such AIV seroprevalence. There are no records from Spheniscus (Smith et al. 2008) or Aptenodytes (Morgan et al. 1981, Gauthier-Clerc et al. 2002, this study). Among Pygoscelis penguins, we found no evidence of exposure to gentoo or chinstrap penguins on Livingston Island in the Antarctic, nor was it recorded among Adélie penguins ( $P$. adeliae (Hombron \& Jacquinot)) at Cape Bird, Antarctica (Austin \& Webster 1993), or gentoo penguins at Macquarie Island (Morgan et al. 1981). However, AIV positive serology has been previously reported from all 
three Pygoscelis penguins (Morgan \& Westbury 1981, Baumeister et al. 2004, Wallensten et al. 2006). By comparison, we recorded seroprevalence among all three Eudyptes penguins sampled, whereas there is only a single previous record for this genus: Miller et al. (2010) recently reported AIV among southern rockhopper penguins from the Falkland Islands. Karesh et al. (1999) failed to detect evidence of AIV exposure in southern rockhopper penguins in Argentina, and neither this species nor royal penguins (E. schlegeli Finsch) tested positive on Macquarie Island (Morgan et al. 1981). Our results suggest that some Eudyptes populations could be prone to be infected by AIV, which would be a rare, temporal pathogen in other penguin genera. In line with our results, evidence of species-specific differences in AIV prevalence has been reported for over 30 bird species (Garamszegi \& Møller 2007, Hanson et al. 2008). For example, Antarctic skuas consistently show some AI seropositive individuals (Austin \& Webster 1993, Baumeister et al. 2004).

Morgan \& Westbury (1981) detected serum antibodies to influenza virus $\mathrm{H7}$ in Adélie penguin colonies in Antarctica, but it was confined to particular colonies. They concluded that not only species-related but also colony-related biases have to be considered when assessing AIV infections. In our study, the higher seroprevalence among macaroni penguins may result from their breeding at higher densities than rockhopper penguins, as both share the same environment and natural resources. However, king penguins also breed in very dense colonies at Marion Island, often adjacent to macaroni penguin colonies, yet they showed no evidence of AIV exposure. Our serology results showed that the AIV N5 subtype had infected one Eudyptes chrysolophus individual, but other infections cannot be ruled out due to cross reactivity in the IHA and INA assays (some penguin sera gave non-specific positive results in the IHA and INA assays) and because the reaction of HA subtypes can differ among NA strains. Virus isolation would be necessary to verify the serology results.

The presence of antibodies indicates previous exposure to a specific pathogen, but it does not necessarily imply the circulation of the pathogen in a particular place, in this case the sub-Antarctic islands, since the contact could have occurred elsewhere. However, most penguins rarely visit land other than their breeding and moulting islands (Marchant \& Higgins 1990) and avian flu is unlikely to be transmitted among individuals at sea. Nevertheless, large numbers of birds migrate to and from northern latitudes to breed or winter in the Southern Ocean, including petrels (e.g. great shearwaters Puffinus gravis (O'Reilly) that breed at Tristan da Cunha and Gough Island and winter in the North Atlantic), skuas (e.g. south polar skuas Catharacta maccormicki Saunders breed on the Antarctic Peninsula and winter in the North Atlantic and North Pacific), and terns (e.g. Arctic terns Sterna paradisaea Pontoppidan breed in Boreal tundras and winter throughout the Southern Ocean).
These species can potentially transmit pathogens to species such as penguins that remain year-round in the Southern Ocean. Alternatively, avian influenza could have been introduced by human activities at research stations or from tourist activities (Weimerskirch 2004). Both locations where we detected AIV in penguins, Gough and Marion islands, have research bases manned year round. However, there have been strict quarantines on poultry products at both islands for the last two decades (no fresh poultry products allowed, only irradiated eggs and deboned chicken meat, and removal of all wastes from the islands for disposal outside the region; Cooper et al. 2009), and the persistence of AIV in the environment from old transmissions to current times is unlikely. The third location, Livingston Island off the Byers Peninsula suffered a relatively low occupancy of sealers in the past and it is currently an Antarctic Specially Protected Area so it is seldom visited, but it is also the location where no positive penguin was found.

None of the seropositive penguins were infected and excreting influenza A virus at the time of sampling. As far as we know, all attempts to detect AIV by using sensitive reverse transcription-polymerase chain reaction, and further isolation from cloacal samples from penguin guano, have been unsuccessful (Briggs et al. 2003, Wallensten et al. 2006, Chang et al. 2009). This same scenario resulted when isolation from penguins was attempted (Morgan \& Westbury 1981, Austin \& Webster 1993).

As expected, our study, like most previous serosurveys of penguins, suggests that AIV occurs at low levels in Antarctic ecosystems. However, its circulation in Antarctic bird populations should not be neglected, particularly where it might affect already threatened species. All three species of Eudyptes penguins that tested seropositive for AIV in our study are listed as either Endangered (northern rockhopper) or Vulnerable (macaroni and southern rockhopper) on the IUCN list of threatened species (www.redlist.org, accessed December 2010). Whether influenza A virus infections affect body condition and general fitness of wild birds, and specifically Antarctic birds, or the other way around (Van Gils et al. 2007, Latorre-Margalef et al. 2009a, 2009b, Flint \& Franson 2009) is still unknown and may need to be tested in experimental conditions. However, their sensitivity to new pathogens is likely to be high and therefore human activities in the region need to integrate procedures to minimize the risk of pathogen dispersal and disease outbreaks among Antarctic wildlife (Cooper et al. 2009, Chown et al. 2012).

\section{Acknowledgements}

As Byers Peninsula is protected, researchers applied for the permits to the Spanish Polar Committee (Polar authority in the country) and the permits were granted to the project's principal investigator. We thank Antje Steinfurth, Rob Ronconi, Jose Antonio Gil Delgado, Antonio Quesada and 
David $\mathrm{H}$ for logistical and fieldwork support, and Raquel Rivas and Erika Serrano, both from CReSA, for their excellent technical assistance. Logistical support at Marion and Gough islands was provided by the South African National Antarctic Programme, Department of Environmental Affairs. This study was funded by the Ministerio de Ciencia e Innovación from the Spanish Government (POL2006-06635, CGL2009-11278/BOS and CTM2011-12973-E). We thank the reviewers for their comments.

\section{References}

Abolnik, C., Gerdes, G.H., Sinclair, M., Ganzevoort, B.W., Kitching, J.P., Burger, C.E., Romito, M., Dreyer, M., Swanepoel, S., Cumming, G.S. \& Olivier, A.J. 2010. Phylogenetic analysis of influenza A viruses (H6N8, H1N8, H4N2, H9N2, H10N7) isolated from wild birds, ducks, and ostriches in South Africa from 2007 to 2009. Avian Diseases, 54, $313-322$.

Austin, F.J. \& Webster, R.G. 1993. Evidence of ortho and paramyxoviruses in fauna from Antarctica. Journal of Wildlife Diseases, 29, 568-571.

Barbosa, A. \& Palacios, M.J. 2009. The health of Antarctic birds: a review of their parasites, pathogens and diseases. Polar Biology, 32, 1095-1115.

Baumeister, E., Leotta, G., Pontoriero, A., Campos, A., Monalti, D., Vig, G., Pecoraro, M. \& Savy, V. 2004. Serological evidence of influenza A virus infection in Antarctica migratory birds. International Congress Series, 1263, 737-740.

Briggs, L.C., Ashton, R.M. \& Metcalf, P. 2003. Development of a highly sensitive screen for influenza $\mathrm{A}$ in guano and its application in the search for ancient RNA preserved under Antarctic Adélie penguins. Avian Diseases, 47, 1200-1202.

Brown, J.D., Luttrell, M.P., Uhart, M.M., Del Valle Ferreyra, H., Romano, M.M., Rago, M.V. \& Stallknecht, D.E. 2010. Antibodies to type A influenza virus in wild waterbirds from Argentina. Journal of Wildlife Diseases, 46, 1040-1045.

Bulach, D., Halpin, R., Sitro, D., Pomeroy, L., Janies, D. \& Boyle, D.B. 2010. Molecular analysis of $\mathrm{H} 7$ avian influenza viruses from Australia and New Zealand: genetic diversity and relationships from 1976 to 2007. Journal of Virology, 84, 9957-9966.

Busquets, N., Alba, A., Napp, S., Sánchez, A., Serrano, E., Rivas, R., NúÑEZ, J.I. \& MAJó, N. 2010. Influenza A virus subtypes in wild birds in north-eastern Spain (Catalonia). Virus Research, 149, 10-18.

Capua, I. \& Alexander, D.J. 2006. The challenge of avian influenza to the veterinary community. Avian Pathology, 35, 189-205.

Chang, C.-M., Lebarbenchon, C., Gauthier-Clerc, M., Le Bohec, C., Beaune, D., Le Maho, Y. \& van der Werf, S. 2009. Molecular surveillance for avian influenza A virus in king penguins (Aptenodytes patagonicus). Polar Biology, 32, 663-665.

Chown, S.L., Lee, J.E., Hughes, K.A., Barnes, J., Barrett, P.J., Bergstrom, D.M., Convey, P., Cowan, D.A., Crosbie, K., Dyer, G., Frenot, Y., Grant, S.M., Herr, D., Kennicutt, M.C., Lamers, M., Murray, A., Possingham, H.P., Reid, K., Riddle, M., Ryan, P.G., Sanson, L., Shaw, J.D., Sparrow, M.D., Summerhayes, C., Terauds, A. \& WaLL, D.H. 2012. Challenges to the future conservation of the Antarctic. Science, 337, 158-159.

Clarke, J. \& Kerry, K. 2000. Disease and parasites of penguin. Penguin Conservation, 13, 5-24.

Cooper, J., Crawford, R.J.M., de Villiers, M., Dyer, B.M., Hofmeyr, G.J.G. \& Jonker, A. 2009. Disease outbreaks among penguins at subAntarctic Marion Island: a conservation concern. Marine Ornithology, 37, 193-196.
Cumming, G.S., Hockey, P.A.R., Bruinzeel, L.W. \& du Plessis, M.A. 2008. Wild bird movements and avian influenza risk mapping in southern Africa. Ecology Society, 13, 26-40.

Davidson, R., Simard, M., Kutz, S.J., Kapel, C.M.O., Hamnes, I.S. \& Robertson, L.J. 2011. Arctic parasitology: why should we care? Trends in Parasitology, 27, 238-244.

Flint, P.L. \& Franson, J.C. 2009. Does influenza A affect body condition of wild mallard ducks, or vice versa? Proceedings of the Royal Society, B276, 2345-2346.

Garamszegi, L.Z. \& Møller, A.P. 2007. Prevalence of avian influenza and host ecology. Proceeding of the Royal Society, B274, 2003-2012.

Gauthier-Clerc, M., Eterradossi, N., Toquin, D., Guittet, M., Kuntz, G. \& Le Maно, Y. 2002. Serological survey of the king penguin, Aptenodytes patagonicus, in Crozet Archipelago for antibodies to infectious bursal disease, influenza A and Newcastle disease viruses. Polar Biology, 25, 316-319.

Ghersi, B.M., Blazes, D.L., Icochea, E., Gonzalez, R.I., Kochel, T., Tinoco, Y., Sovero, M.M., Lindstrom, S., Shu, B., Kuimov, A., GonZalez, A.E. \& Montgomery, J.M. 2009. Avian influenza in wild birds, central coast of Peru. Emerging Infectious Diseases, 15, 935-938.

Hanson, B.A., Lutrell, M.P., GoekJian, V.H., Niles, L., Swayne, D.E., SenNe, D.A. \& Stallknecht, D.E. 2008. Is the occurrence of avian influenza virus in charadriiformes species and location dependent? Journal of Wildlife Diseases, 44, 351-361.

Karesh, W.B., Uhart, M.M., Frere, E., Gandini, P., Braselton, W.E., Puche, H. \& Соок, R.A. 1999. Health evaluation of free-ranging rockhopper penguins (Eudyptes chrysocome) in Argentina. Journal of Zoo and Wildlife Medicine, 30, 25-31.

Latorre-Margalef, N., Gunnarsson, G., Munster, V.J., Fouchier, R.A.M., Osterhaus, A.D.M.E., Elmberg, J., Olsen, B., Wallensten, A., Fransson, T., Brudin, L. \& Waldesntröm, J. 2009a. Effects of influenza A virus infection on migrating mallard ducks. Proceedings of the Royal Society, B276, 1029-1036.

Latorre-Margalef, N., Gunnarsson, G., Munster, V.J., Fouchier, R.A.M., Osterhaus, A.D.M.E., Elmberg, J., Olsen, B., Wallensten, A., Fransson, T., Brudin, L. \& Waldenström, J. 2009b. Does influenza A affect body condition of wild mallard ducks, or vice versa? A reply to Flint and Franson. Proceedings of the Royal Society, B276, 2347-2349.

Marchant, S. \& Higgins, P.J. 1990. Handbook of Australian, New Zealand and Antarctic birds, vol. 1. Ratites to ducks. Melbourne: Oxford University Press, $1048 \mathrm{pp}$.

Miller, P.J., Afonso, C.L., Spackman, E., Scott, M.A., Pedersen, J.C., Senne, D.A., Brown, J.D., Fuller, C.M., Uhart, M.M., Karesh, W.B. \& BRown, I.H. 2010. Evidence for a new avian paramyxovirus serotype 10 detected in rockhopper penguins from the Falkland Islands. Journal of Virology, 84, 11 496-11 504.

Møller, A.P., Arriero, E., Lobato, E. \& Merino, S. 2009. A meta-analysis of parasite virulence in nestling birds. Biology Reviews, 84, 567-588.

Morgan, I.R. \& Westbury, H.A. 1981. Virological studies of Adélie penguins. Avian Diseases, 25, 1019-1026.

Morgan, I.R., Westbury, H.A., Caple, I.W. \& CAmpbell, J. 1981. A survey of virus infection in sub-Antarctic penguins on Macquarie Island, Southern Ocean. Australian Veterinary Journal, 57, 333-335.

Munster, V.J., BaAs, C., Lexmond, P., Waldenström, J., Wallensten, A., Fransson, T., Rimmelzwan, G.F., Beyer, W.E.P., Schutten, M., Olsen, B., Osterhaus, A.D.M.E. \& Fouchier, R.A.M. 2007. Spatial, temporal, and species variation in prevalence of influenza $A$ viruses in wild migratory birds. PLoS Pathogens, 3, e61.

Olsen, B., Munster, V.J., Wallensten, A., Waldenström, J., Osterhaus, A.D.M.E. \& Fouchier, R.A.M. 2006. Global patterns of influenza A virus in wild birds. Science, 312, 384-388.

Smith, K.M., Karesh, W.B., Majluf, P., Paredes, R., Zavalaga, C., Reul, A.H., Stetter, M., Braselton, W.E., Puche, H. \& Cook, R.A. 2008. Health evaluation of free-ranging Humboldt penguins (Sphenicus humboldti) in Peru. Avian Diseases, 52, 130-135. 
Spackman, E., Senne, D.A., Myers, T.J., Bulaga, L.L., Garber, L.P., Perdue, M.L., Lohman, K., Daum, L.T. \& Suarez, D.L. 2002. Development of a real-time reverse transcriptase PCR assay for type A influenza virus and the avian $\mathrm{H} 5$ and $\mathrm{H} 7$ hemagglutinin subtypes. Journal of Clinical Microbiology, 9, 3256-3260.

Tong, S., Li, Y., Rivailler, P., Conrady, C., Alvarez Castillo, D.A., Chen, L.-M., Recuenco, S., Ellison, J.A., Davis, C.T., York, I.A., Turmelle, A.S., Moran, D., Rogers, S., Shi, M., Tao, Y., Weil, M.R., Tang, K., Rowe, L.A., Sammons, S., Xu, X., Frace, M., Lindblade, K.A., Cox, N.J., Anderson, L.J., Rupprecht, C.E. \& Donis, R.O. 2012. A distinct lineage of influenza A virus from bats. Proceedings of the National Academy of Sciences of the United States of America, 109, 4269-4274.
Van Gils, J.A., Munster, V.J., Radersma, R., Liefhebber, D., Fouchier, R.A.M. \& KLAassen, M. 2007. Hampered foraging and migratory performance in swans infected with low-pathogenic avian influenza A virus. PloS One, 2, e184.

Wallensten, A., Munster, V.J., Osterhaus, A.D.M.E., Waldenström, J., Bonnedahl, J., Broman, T., Fouchier, R.A.M. \& Olsen, B. 2006. Mounting evidence for the presence of influenza A virus in the avifauna of the Antarctic region. Antarctic Science, 18, 353-356.

Webster, R.G., Bean, W.J., Gorman, O.T., Chambers, T.M. \& Kawaoka, Y. 1992. Evolution and ecology of influenza A viruses. Microbiology Reviews, 56, 152-179.

Weimerskirch, H. 2004. Diseases threaten Southern Ocean albatrosses. Polar Biology, 27, 374-379. 